\title{
Mathematical model for dynamic cell formation in fast fashion apparel manufacturing stage
}

\author{
Gayathri Perera ${ }^{1} \cdot$ Vijitha Ratnayake $^{1}$
}

Received: 14 September 2017 / Accepted: 16 May 2018/Published online: 29 May 2018

(C) The Author(s) 2018

\begin{abstract}
This paper presents a mathematical programming model for dynamic cell formation to minimize changeover-related costs (i.e., machine relocation costs and machine setup cost) and inter-cell material handling cost to cope with the volatile production environments in apparel manufacturing industry. The model is formulated through findings of a comprehensive literature review. Developed model is validated based on data collected from three different factories in apparel industry, manufacturing fast fashion products. A program code is developed using Lingo 16.0 software package to generate optimal cells for developed model and to determine the possible cost-saving percentage when the existing layouts used in three factories are replaced by generated optimal cells. The optimal cells generated by developed mathematical model result in significant cost saving when compared with existing product layouts used in production/assembly department of selected factories in apparel industry. The developed model can be considered as effective in minimizing the considered cost terms in dynamic production environment of fast fashion apparel manufacturing industry. Findings of this paper can be used for further researches on minimizing the changeover-related costs in fast fashion apparel production stage.
\end{abstract}

Keywords Dynamic cell $\cdot$ Labor-intensive $\cdot$ Apparel $\cdot$ Product layout $\cdot$ Changeover $\cdot$ Cost saving

\section{Introduction}

Fast fashion apparels are highly fashionable products with affordable prices in the mid-to-low range, which demands for quick response and frequent assortment changes (Vecchi and Buckley 2016; Elavia 2014; Caro and Martínez-de-Albéniz 2015; Cachon and Swinney 2011). As mentioned by Bhardwaj and Fairhurst (2009), Jovanovic et al. (2014), Memic and Minhas (2011) and Cachon and Swinney (2011), frequent fluctuation of customer demand with smaller batch quantities and, short production and distribution lead-times, are the key characteristics of fast fashion apparels. Because of the increasing consumer demand, fast fashion segment in apparel industry has shown a rapid growth internationally during past few years

Gayathri Perera upamali28@gmail.com

Vijitha Ratnayake vijithar@uom.lk

1 Department of Textile and Clothing Technology, University of Moratuwa, Moratuwa, Sri Lanka
(Mo 2015; Jovanovic et al. 2014; Moretta Tartaglione and Antonucci 2013; Aus 2011). More importantly, Caro and Martínez-de-Albéniz (2015) stated it as a high growth potential area of international apparel business.

In order to remain competitive in dynamic market conditions of fast fashion apparel industry, the apparel manufacturers are under immense pressure to achieve high degree of manufacturing flexibility (Caro and Martínez-deAlbéniz 2015; Jovanovic et al. 2014). Low manufacturing cost is another important aspect that determines the competitiveness of manufacturing industries (Bayram and Sahin 2016; Khannan et al. 2016). Hence, it is essential to focus on improving manufacturing flexibility while ensuring low manufacturing cost to survive under volatile market conditions.

Several authors have emphasized the need of improving layout flexibility in order to increase the manufacturing flexibility (Neumann and Fogliatto 2013; Raman et al. 2009). Incorporating flexible layouts that can accommodate dynamic production environments while ensuring minimum manufacturing cost is vital to be competitive in 
volatile market conditions (De Carlo et al. 2013; Hamedi et al. 2012).

Niakan et al. (2016) and Nouri (2016) suggested Dynamic Cellular Manufacturing System (DCMS) as the most suitable approach in achieving high degree of flexibility and agility to manage changes in product mix.

High degree of manufacturing flexibility can be achieved by minimizing changeover time between different products (De Carlo et al. 2013; Neumann and Fogliatto 2013; Egilmez et al. 2012). Several authors have stated that dynamic cellular layouts show promising results in minimizing changeover times of industries with volatile demand conditions (Bayram and Sahin 2016; Dalfard 2013; Asgharpour and Javadian; 2004). Hence, minimization of changeover-related cost has become one of the primary objectives of dynamic cellular layout designs. Furthermore, as stated by Shafigh et al. (2017) about $20-50 \%$ of the manufacturing cost is related to material handling. Minimization of material handling cost is the most prominent cost function used in available studies on mathematical programming of DCMS designs (Sakhaii et al. 2016; Moradgholi et al. 2016). A well-designed layout can minimize manufacturing cost through effective minimization of the material handling costs (Shafigh et al. 2017; Chang et al. 2013)

According to Bayram and Sahin (2016), and Kia et al. (2013) cell formation, group layout, group scheduling and resource allocation are four basic stages of designing Cellular Manufacturing System (CMS). As the first step of CMS design, Cell Formation (CF) seeks to assign parts to their respective families and grouping the corresponding machines to relevant machine cells. A part family comprises of part types having similar manufacturing characteristics, product design features, product demand, processing requirements, etc. (Mahdavi et al. 2013; Dalfard 2013). Construction of part families and machine cells, and assignment of part families to respective machine cells is done by optimizing a selected set of performance measures such as material handling cost, machine setup cost, grouping efficacy and exceptional elements (Deep and Singh 2015; Bagheri and Bashiri 2014; Rafiei and Ghodsi 2013).

This paper addresses the first stage of CMS design under dynamic environment (i.e., CF). This paper presents a mathematical programming model developed for the Dynamic Cell Formation (DCF) that aims to generate optimal cells that can minimize the costs of machine relocation, machine setup and inter-cell material handling of production environment with machine reliability issues in a labor-intensive apparel manufacturing industry under volatile demand conditions of fast fashion apparels. Performance of the developed model is validated based on data collected from actual production environments of three apparel manufacturing factories that are currently manufacturing fast fashion products. These factories use product layout in their production environments. Numerical results of developed model show that dynamic cellular layouts lead to significant cost saving when it is applied to volatile production environments that are currently using product layout.

\section{Literature review}

\section{CMS design approaches}

Group Technology (GT) is one of the most widely used approaches in handling shorter product life cycles and high variety of products with minimum manufacturing costs (Nunkaew and Phruksaphanrat 2013; Rafiei and Ghodsi 2013). GT is a manufacturing philosophy that exploits the similarities within a manufacturing system. Under GT, products with similar design and manufacturing characteristics are grouped into product families (Rajput 2007) and relevant machines that are required to process the product families are grouped into GT cells (Giri and Moulick 2016).

CMS is the corresponding feature of GT to the layout of manufacturing industries. Reduced setup time and cost required to perform setups, simplified material flows and reduced material handling, reduced work-in-progress inventory, reduced throughput time and improved sequencing and scheduling on the shop floor are some of the most outstanding benefits of CMS (Nunkaew and Phruksaphanrat 2013; Modrák 2011; Hachicha et al. 2006). The main purpose of CMS is to retain benefits of high productivity in product layout and flexibility of processoriented layouts (Rajput 2007; Case and Newman 2004).

As mentioned by Bayram and Sahin (2016), Kia et al. (2013) and Mahdavi et al. (2013), designing of a CMS comprise of four stages as $\mathrm{CF}$, group layout, group scheduling and resource allocation.

Cell Formation Problem (CFP) involves grouping machines and products into families based on their similarities (Rajput 2007). Routing similarities and/or processing similarities are used to generate product families. These two types of similarities are likely to occur more or less independent to each other. In other words, products that require same operation do not necessarily share similar routings. Best approach to address the CFP is combining both routing and processing similarities such that resultant product family has a set of products with similar operations and similar routes (Kumar and Moulick 2016).

Three main approaches are used to address the CFP (Kahraman 2012; Modrák 2011; Curry and Feldman 2010).

They are: 
1. Product family identification (PFI),

2. Machine group identification (MGI),

3. Product families/machine grouping (PF/MG).

In the first approach, initially the product families are identified by using an appropriate technique. Thereafter, the machines are allocated to the respective product families. Machine group identification (MGI) approach groups the machines into cells based on routing similarities followed by assignment of product families to the formed cells. In the third approach, product family formation and machine grouping are done simultaneously. Out of these, the third approach is highlighted as optimum CF method (Kahraman 2012; Mungwattana 2000).

According to Kia et al. (2013), group layout of CMS design deals with two aspects as inter-cell layout and intracell layout. Inter-cell layout determines the location of cells with respect to each other whereas intra-cell layout considers machine arrangement with each cell (Mahdhavi et al. 2013). Scheduling of part families is done in third stage of CMS design (Kia et al. 2013). Resource allocation stage consists of assignment of required resources to the cells (i.e., man, material and other required tools.).

Based on the production requirements and desired design attributes, CMS can be broadly categorized into two segments as Static Cellular Manufacturing System (SCMS) and Dynamic Cellular Manufacturing System (DCMS) (Niakan et al. 2016; Khannan et al. 2016).

Designing of a SCMS is done by assuming deterministic product demand and product mix for the considered planning horizon (Hachicha et al. 2006). In other words, it is assumed that the product demand and product mix are known with certainty for the periods in considered planning horizon. In SCMS, cells that optimize the selected performance measures for all the product demand and product mix are used for the entire planning horizon considered in SCMS design (Hachicha et al. 2006).

As stated by Houshyar et al. (2014), presently the low volume-high variety products with volatile demand and shorter lead-times are popular in most of the industries. Optimal cells of a particular period may not be optimal for other periods due to possible variations of production requirements of different product mixes (Niakan et al. 2016; Deep and Singh 2016). According to Niakan et al. (2016), static cells are beneficial if the same product mix is manufactured for entire planning horizon or the new products are perfectly matched with existing product families being manufactured in static cells. Pillai et al. (2011), Modrák (2011) and, Marsh et al. (1997) argued that the static cells are inflexible for introduction of completely new product mix. Introduction of new products to the static cells result in deteriorate of the cell performance and eventually cause a major rearrangement of machines
(Balakrishnan and Hung Cheng 2005; Chowdary et al. 2005). Furthermore, Marsh et al. (1997) argued that static cells are associated with low routing flexibility. It will directly deteriorate the layout flexibility (Neumann and Fogliatto 2013).

DCMS is introduced to overcome the drawbacks of CMS. As mentioned by Niakan et al. (2016), Deep and Singh (2016) and Mahdavi et al. (2010), DCF is done by dividing considered planning horizon into multiple planning periods. Instead of using stable product mix and demand for entire planning horizon, the dynamic cellular layouts are formed by considering possible variations in multiple periods (Niakan 2015). These variations require reconfiguration of the dynamic cells (Niakan 2015; Houshyar et al. 2014). Cell reconfigurations are minimized by considering all the possible demands in corresponding planning horizon and optimizing the selected performance measures for considered planning horizon and defined planning periods (Niakan et al. 2016; Süer et al. 2010). As stated by Niakan (2015) and Houshyar et al. (2014), layout reconfiguration of dynamic cells is done by switching of existing machines between cells, adding new machines to the cells and removing existing machines from cells.

As stated by Mungwattana (2000), four basic types of production requirement are considered in GT-based cellular layout designs. They are static, dynamic, stochastic and deterministic. Production requirement in any industry can be represented by using one or more of these types. Static production requirement assumes a constant product mix and demand for entire planning horizon. There can be either static-deterministic production requirement or staticstochastic production requirement. In first case, the product mix and demand for entire period is exactly known at the cell formation stage. For the second one, possible product mix and demand for the period is known with certain probabilities. Similarly, dynamic cells incorporate the possible production requirements in either stochastic or deterministic nature (Balakrishnan and Hung Cheng 2005; Mungwattana 2000). In both types of product demand, dynamic cells form physical grouping of cells based on GT principles while rearranging the cells when necessary. This allows the dynamic cellular layouts to retain the flexibility through cell reconfiguration on a planned basis and to gain advantages of static cells. Excessive rearrangement of cells may significantly increase cost of machine movement and lost of production time (Kia et al. 2013). Conversely, increasing robustness for multiple demand scenarios deteriorates the cell performance due to increased material handling. Furthermore, using an inappropriate cell layout for a particular period may lead to increased reconfiguration costs in subsequent periods (Niakan 2015). Designing process of DCMS aims to obtain optimal cells by balancing these two conflicting scenarios. 


\section{Machine-intensive and labor-intensive manufacturing cells}

As mentioned by Egilmez et al. (2012), manufacturing cells can be either machine-intensive or labor-intensive. Limited operator involvement in operations is the key characteristic of machine-intensive cells. Operators load the raw material or half-assembled product to the machine, control quality and unload the output from machine.

In labor-intensive cells, complete operator involvement in operations is essential and the output and performance of operation significantly fluctuate based on operator-related factors (Zhao and Yang 2011). As mentioned by Süer and Dagli (2005), labor-intensive cells consist of lightweight small machines and equipments that are easy to relocate. Utilization of the existing machines is encouraged in laborintensive manufacturing cells (Süer and Dagli 2005).

Production/assembly department of apparel industry is known as highly labor-intensive (Islam et al. 2015; Guo et al. 2015). According to Zhao and Yang (2011) and Mittlehauser (1997), machines used in production department of apparel manufacturing factories can be categorized into two types based on the level of operator intervention to complete an operation.

Fully automatic machines Operators load the raw material or half-assembled product to the machine, monitor the quality and unload output from machine. Machines can be pre-programmed to operate automatically with little intervention of the operator. Examples for such machines are button-hole, bar-tack and pocket sewer machines.

Semi-automatic machines Operator should continually attend to control the machine to process a particular operation.

\section{DCMS design with labor-related issues}

Nonlinear integer programming model for dynamic cell formation is developed by Mahdavi et al. (2010) to address the problem of operator assignment to cells. Improving operator assignment flexibility concurrently with dynamic cell formation is the main feature of the developed model. Multiple attributes are considered in their model as; multiperiod production planning, machine duplication, dynamic system reconfiguration, machine capacity, available time of operators and operator assignment. The objective function seeks to minimize eight cost functions namely; holding cost, backorder cost, inter-cell material handling cost, maintenance and overhead cost of machines, machine relocation cost, salary cost, hiring cost and firing cost. Mahdavi et al. (2010) emphasized the need of considering operator-related factors in cell design to achieve expected benefits of cellular layouts. Niakan et al. (2016) introduced a biobjective mathematical model for dynamic cell formation by considering both machine and operator skill levels. Niakan et al. (2016) formulated and validated their model by using theoretical data sets. Sakhaii et al. (2016) developed a robust optimization approach for a mixed-integer linear programming model to obtain solutions for a DCMS with unreliable machines and a production planning problem in a simultaneous manner. Main considerations of their study are DCFP, inter-cell layout, operator assignment problem, unreliable machines, alternative process routes and production planning decisions. Objective function of the mathematical model developed by Sakhaii et al. (2016) sought to minimize the costs of inter- and intra-cell material handling, operator training and hiring, machine relocation, machine breakdowns, inventory holding and backorder. The biobjective stochastic model developed by Zohrevand et al. (2016) addresses human-related problems in DCFP by considering labor utilization, worker overtime cost, worker hiring/laying-off, and worker cell assignment. Their model seeks to minimize the total costs of machine procurement, machine relocation, inter-cell moves, overtime utilization, worker hiring/laying-off, and worker moves between cells while maximizing the labor utilization. The model proposed by Tavakkoli-Moghaddam et al. (2011) is one of the noticeable studies on incorporating human-related factors in cell formation. Their model consists of cell formation problem with two conflicting objectives as; optimizing the labor allocation while maximizing the cell utilization. The developed model is solved using multiobjective particle swarm optimization.

\section{Impact of machine breakdowns on DCMS design}

Machine breakdowns in the system play a major role in determining the available capacity for production. There are two main categories of machine breakdown as; Chronic breakdowns and Sporadic breakdowns. As stated by Ireland and Dale (2001) and Cheng and Podolsky (1996), five common causes of chronic breakdowns are:

1. Failure to maintain machines, i.e., cleaning and minor repairs,

2. Failure to maintain operating conditions such as temperature, speed,

3. Insufficient operator skills such as improper and erroneous machine handling,

4. Deterioration of machine parts,

5. Poor design of machine parts due to wrong materials and sizes.

In the presence of chronic breakdowns, operators are able to perform required operations but with reduced speed. These breakdowns are continual and may result in minor stoppages that can be repaired within a short time (Ireland 
and Dale 2001; Leflar 2001). Neglecting the chronic breakdowns leads to sporadic breakdowns, which are suddenly exposed and unexpected. Badiger and Laxman (2013) discussed that sporadic breakdowns can cease entire operation and it typically requires major troubleshooting to restore the machine to working condition or to replace with new machine.

Machine breakdowns restrain the machine availability when designing a DCMS (Esmailnezhad et al. 2015; Houshyar et al. 2014). Majority of the previous CMS design considered $100 \%$ machine reliability, which is practically hard to achieve (Nouri et al. 2014; Saxena and Jain 2011; Chung et al. 2011). As stated by Kannan (2011), the severity of machine reliability issues is high in CMS. Reason for that is failure of any machine/tools assigned for a particular cell will halt entire production of the manufacturing cell (Kannan 2011). According to Houshyar et al. (2014), machine breakdowns have direct influence on due dates and optimal cost of the system. Seifoddini and Djassemi (2001) stated that machine breakdowns have greater effect on productivity of entire manufacturing operations. Machine breakdowns are a crucial factor that must be incorporated in designing of CMS (Houshyar et al. 2014; Chung et al. 2011). One of the studies that incorporate variable failure rates of the machines is the model proposed by Yadollahi et al. (2014). The objective functions of their model are minimizing the purchase cost of machines, intra-cellular movements and the inter-cellular movement costs of materials while minimizing the total repair time for failed machines.

\section{Model formulation}

Mathematical model is formulated to generate optimal dynamic cells that can ensure minimum costs of machine relocation, machine setup and inter-cell material handling in labor-intensive production environments subjected to machine breakdowns.

It is assumed that a specific area is used to perform machine setup activities (if needed). It is referred as setup area. In the developed model, excessive machines in particular period are stored in setup area. Machines with completed setup activities required for a particular period are moved from this area to the corresponding cell. Possible scenarios of machine relocations in the developed model can be listed as follows:

i) Moving machines between different cells,

ii) Moving machines between cells and setup area.

In the mathematical model development, summation of costs for above two relocations is referred as total machine relocation cost.
Two possible machine setup scenarios considered in the developed model are:

(i) Machines required for particular operations in current period are available in dynamic cells of previous period and it is needed to perform different machine settings to use them in current period.

(ii) Machines required for particular operations in current period are not available in dynamic cells of previous period and required machine setup activities are performed in setup area.

Inter-cell material handling cost occurs when a particular part requires a machine that is located outside of the cell assigned for that part type.

It is assumed that the material handling between operations is done manually without using an automated system. Labor-intensive cells consist of lightweight small machines and equipments that are easy to relocate (Süer and Dagli 2005). Hence, an assumption is made as the machine movements between two locations are done by using manual trolleys. According to Heizer (2016) and Chary (1988) Method Time Measurement (MTM) system provides standard times for elements of fixed standard categories of work motions such as reach, move, turn, grasp. MTM data are widely used when determining the standard times of manual operations (Aft 2000). MTM values are used when calculating the time taken for respective material and machine movements of developed model.

\section{Development of mathematical programming model}

\section{Assumptions}

1. Each part type has a set of operations that must be processed based on the given operation sequence.

2. Product mix and respective demand for each part type are known in advance.

3. Each machine has a limited capacity in each period and it is expressed in minutes.

4. Each machine is capable of processing more than one operation.

5. Standard processing times for each operation and setup times for each machine setup activity are known.

6. All the operators and mechanics are multi-skilled. Hence, no additional training is required during product changeovers.

7. Multi-skilled operator pool is available to mitigate the effects of absenteeism. 
8. There are no delays due to raw material supply, management failures or power failures.

9. Production requirement is dynamic-deterministic.

10. Cell reconfiguration (if any) involves machine setup activities and machine relocations between and/or within the cells.

11. Physical partitioning of the cells is prohibited. Furthermore, cell reconfiguration does not require modifications to the buildings. Therefore, other than the machine relocation costs, any physical reconfiguration costs (i.e., changes in lighting and ventilation systems) are not allowed.

12. Adequate lighting and environmental conditions required for the operations are provided.

13. Multiple duplicate machines of each type are available. Existing machines at the beginning of each period are utilized when developing dynamic cells. Therefore, machine procurement is excluded.

14. Machine availability is limited due to machine breakdowns.

15. Preventive maintenance activities are done outside the plant floor and it do not affect the numbers of machines available within the floor.

16. Inter-cell material handling cost does not depend on the product type.

17. Handling of materials in cells and machine movements are done manually.

18. Cost per unit time for each period is known.

\section{Indices}

$h:$ Index for period $; h=1,2, \ldots, H$

$t:$ Index for part type $t=1,2, \ldots, T$

$n:$ Index for number of operations $; n=1,2, \ldots, N$

$O_{t, n}:$ Index for operation $n$ of part type $t$

$i$ : Index for machine types; $i, i^{\prime}=1,2, \ldots, I$

$j$ : Index for machine number in each machine type;

$j, j^{\prime}=1,2, \ldots, J$

$m_{i, j}$ : Index for $j$ th machine of machine type $i$

$l:$ Index for machine setting; $l=1,2, \ldots, L$

$k:$ Index for cells; $k, k^{\prime}=1,2, \ldots \ldots, K$

\section{Input parameters}

$T:$ Number of part types in planning horizon

$N$ : Number of operations in each part type

$I:$ Number of available machine types

$J$ : Number of machines available from each machine type

$H$ : Number of periods in planning horizon

$L:$ Number of available machine settings
$D_{t, h}$ : Demand quantity for part type $t$ during period $h$

$\eta_{O_{t, n}, m_{i, j}}:$ Standard processing time for operation $n$ of part type $t$ on machine $m_{i, j}$

$U_{m_{i, j}}$ : Time taken to load and unload machine $m_{i, j}$ to/

from the trolley

$\gamma_{h}$ : Cost per minute value during period $h$

$\varphi_{l, m_{i, j}}:$ Time to perform machine setting $l$ on

machine, $m_{i, j}$

$\vartheta_{h, m_{i, j}}$ : Total number of machines in plant floor during period $h$

$\lambda$ : Number of turning motions when moving materials between cells

$\tau_{m_{i, j}}$ : Non - negative random number for corrective

repair time of machine $m_{i j}$

$d F_{t, m_{i, j}}(h)$ : Breakdown rate of machine $m_{i, j} \quad$ when

processing part type $t$ during period $h$

$\Omega_{h, m_{i, j}}$ : Capacity of machine $m_{i, j}$ during period $h$ (given

in minutes)

$\omega_{m_{i, j}, l, O_{t, n}}= \begin{cases}1 & \begin{array}{l}\text { if operation } n \text { of part type } t \text { requires } \\ \text { machine } m_{i, j} \text { with setting } l \\ 0 \\ \text { otherwise }\end{array}\end{cases}$

\section{Decision variables}

Integer variables $f_{t, m_{i, j}, m_{l^{\prime}, j^{\prime}}}$ : Number of times that an operation at machine $m_{i, j}$ immediately follows an operation at machine $m_{i^{\prime}, j^{\prime}}$ or vice versa

\section{Binary variables}

$$
\begin{aligned}
& \delta_{h, m_{i, j}}= \begin{cases}1 & \text { if machine } m_{i, j} \text { is at machine set }- \text { up area during period } h \\
0 & \text { otherwise }\end{cases} \\
& b_{k, h, m_{i, j}}= \begin{cases}1 & \text { if machine } m_{i, j} \text { is in cell } k \text { during period } h \\
0 & \text { otherwise }\end{cases} \\
& e_{l, h, m_{i, j}}= \begin{cases}1 & \text { if machine } m_{i, j} \text { is with setting } l \text { during period } h \\
0 & \text { otherwise }\end{cases} \\
& \mu_{m_{i, j}, O_{t, n}}= \begin{cases}1 & \text { if machine } m_{i, j} \text { is required for operation } n \text { of part type } t \\
0 & \text { otherwise }\end{cases} \\
& \theta_{t, k, h}= \begin{cases}1 & \text { if part type } t \text { is assigned to cell } k \text { during period } h \\
0 & \text { otherwise }\end{cases}
\end{aligned}
$$

Objective function seeks to minimize the summation of total machine relocation cost, machine setup cost and intercell material handling cost. Formulation of objective function and constraints of developed mathematical programming model are discussed hereafter. 


\section{Mathematical model}

$$
\operatorname{Min}(\mathrm{EMRC}+\mathrm{MSC}+\mathrm{EMHC})
$$

$$
\mathrm{EMRC}=\mathrm{MRC}_{\mathrm{A}}+\mathrm{MRC}_{\mathrm{B}}
$$

$$
\begin{aligned}
\operatorname{MRC}_{\mathrm{A}}= & \sum_{h=1}^{H} \sum_{k=1}^{K} \sum_{\substack{k^{\prime}=1 \\
k \neq k^{\prime}}}^{K} \sum_{\substack{i=1 \\
m_{l, J}}}^{m_{1}}\left(1-b_{k^{\prime}, h, m_{i, j}}\right)\left(1-b_{k,(h+1), m_{i, j}}\right) . \\
& b_{k, h, m_{i, j}} \cdot b_{k^{\prime},(h+1), m_{i, j}} \cdot\left(U_{m_{i, j}}+0.0102 \operatorname{dis}_{k, k^{\prime}}\right) \cdot \gamma_{(h+1)}
\end{aligned}
$$

$$
\begin{gathered}
\operatorname{MRC}_{\mathrm{B}}=\sum_{h=1}^{H} \sum_{k=1}^{K} \sum_{\substack{k^{\prime}=1 \\
k \neq k^{\prime}}}^{K} \sum_{i=1}^{m_{I, J}}\left(1-b_{k, h, m_{i, j}}\right)\left(1-b_{k^{\prime}, h, m_{i, j}}\right) \cdot \delta_{h, m_{i, j}} . \\
b_{k,(h+1), m_{i, j}} \cdot\left(U_{m_{i, j}}+0.0102 \operatorname{dis}_{k, D}\right) \cdot \gamma_{(h+1)}
\end{gathered}
$$

$$
\begin{aligned}
& \text { MSC }=\sum_{h=1}^{H} \sum_{k=1}^{K} \sum_{\substack{i=1 \\
j=1}}^{m_{l, J}} \sum_{l=1}^{L} \sum_{\substack{l^{\prime}=1 \\
l \neq l^{\prime}=1 n}}^{L} \sum_{\substack{t=1 \\
O_{T, N}}}^{O_{k,(h+1), m_{i, j}}} \mu_{m_{i, j}, O_{t, n}} . \\
& \omega_{m_{i, j}, l^{\prime}, O_{t, n}} \cdot e_{l^{\prime},(h+1), m_{i, j}} \cdot e_{l, h, m_{i, j}} \cdot \varphi_{l^{\prime}, m_{i, j}} \cdot \gamma_{(h+1)}
\end{aligned}
$$

$$
\begin{gathered}
\mathrm{EMHC}=\sum_{h}^{P_{h}} \sum_{\substack{i \neq i^{\prime} \\
j \neq j^{\prime}}}^{m_{i j}} \sum_{k}^{C_{k}} \sum_{k \neq k^{\prime}}^{C_{k}} \sum_{t, n}^{O_{t h}} \sum_{t}^{T} D_{t, h} \cdot b_{k, h, m_{i, j}} \cdot \mu_{m_{i, j}, O_{t, n}} . \\
b_{k^{\prime}, h, m_{i^{\prime}, j^{\prime}}} \cdot \mu_{m_{i^{\prime}, j^{\prime}}, O_{t,(n+1)}} f_{t, m_{i, j}, m_{i^{\prime}, j^{\prime}}} \cdot\left(0.0102 d i s_{k, k^{\prime}}+0.02232 \lambda\right) . \\
\gamma_{h} \quad \forall i \neq i^{\prime}, j \neq j^{\prime}
\end{gathered}
$$

Subject to:

$$
\begin{aligned}
f_{t, m_{i, j} m_{i^{\prime}, j^{\prime}}} & =\sum_{n=1}^{O_{T(N-1)}}\left(\mu_{m_{i, j}, O_{t, n}} \cdot \mu_{m_{i^{\prime}, j^{\prime}}, O_{t,(n+1)}}+\mu_{m_{i^{\prime}, j^{\prime}}, O_{t, n}} \cdot \mu_{m_{i, j}, O_{t,(n+1)}}\right) ; \\
\forall t, m_{i^{\prime}, j^{\prime}} & >m_{i, j}
\end{aligned}
$$$$
\vartheta_{h, m_{i, j}} \geq \sum_{k=1}^{K} \sum_{\substack{i=1 \\ j=1}}^{m_{I, J}} b_{k, h, m_{i, j}}+\sum_{\substack{i=1 \\ j=1}}^{m_{I, J}} \delta_{h, m_{i, j}} ; \quad \forall m_{i, j}, k, h
$$

$$
\sum_{\substack{i=1 \\ j=1}}^{m_{I, J}} \sum_{\substack{t=1 \\ n=1}}^{O_{T, N}} D_{t, h} \cdot \eta_{O_{t, n}, m_{i, j}}=\frac{q}{K}\left(\sum_{k=1}^{K} \sum_{\substack{i=1 \\ j=1}}^{m_{I, J}} \sum_{\substack{i=1 \\ j=1}}^{O_{T, N}} D_{t, h} \cdot \eta_{O_{t, n}, m_{i, j}}\right) ;
$$$$
\forall m_{i j}, k, h
$$

$$
\begin{aligned}
& \sum_{h=1}^{H} \sum_{k=1}^{K} \sum_{\substack{t=1 \\
n=1}}^{O_{T, N}} \sum_{\substack{i=1 \\
j=1}}^{m_{I, J}} \eta_{O_{t, n}, m_{i, j}} . D_{t, h} \cdot \mu_{m_{i, j}, O_{t, n}} \cdot b_{k, h, m_{i, j}} \\
& \leq \sum_{\substack{i=1 \\
j=1}}^{m_{I, J}} b_{k, h, m_{i, j}}\left(\Omega_{h, m_{i, j}}-\int_{0}^{\Omega_{h, m_{i, j}}} \tau_{m_{i, j}} d F_{t, m_{i, j}}(h)\right) \\
& -\sum_{l=1}^{L} \sum_{\substack{i=1 \\
j=1}}^{m_{l, J}} \varphi_{l, m_{i, j}} ; \quad \forall k \\
& \sum_{t=1}^{T} \theta_{t, k, h}=1 ; \forall k, h \\
& H, R, K, f_{t, m_{i, j} m_{i^{\prime} j^{\prime}}} \geq 0 \text { and integer; } \quad \forall h, k, t, m_{i, j} \\
& \delta_{h, m_{i, j}}, \omega_{m_{i, j}, l, O_{t, n}}, b_{k, h, m_{i, j}}, e_{l, h, m_{i j}}, \mu_{m_{i, j}, o_{t, n}}, \theta_{t, k, h} \in\{0,1\}
\end{aligned}
$$

The objective function is shown in Eq. (1). Detailed description of each cost term and constraint is presented hereafter.

EMRC is the total cost for following activities during layout reconfigurations.

- Loading machine to the manually operated trolley

- Transporting machine to required locations

- Unloading machine from manually operated trolley

Mital et al. (2017) and Karger and Bayha (1987) stated that walking time per foot value when transporting machines using manually operated trolleys in obstructed paths is 17 TMU (Time Measurement Unit) or $0.0102 \mathrm{~min}$ as per MTM systems. Total machine relocation cost for considered planning periods is calculated by Eq. (1.1). Equation (1.2) calculates the machine relocation cost between cells, whereas machine relocation cost between cells and setup area is calculated by Eq. (1.3).

Specific setup activities must be performed when two operations can be processed at same machine but with different machine settings in consecutive periods. Total machine setup time when converting from one machine setting to another is used to calculate machine setup cost for each machine. If the machine requires same setting for two consecutive periods, no setup activity for such machines is performed. Machine setup cost for considered planning periods is calculated as given in Eq. (1.4). 
Operators' walking between cells will possibly restrict due to movement of other operators and machines. As stated by Mital et al. (2017) and Karger and Bayha (1987), walking time per foot is $17.0 \mathrm{TMU}(0.0102 \mathrm{~min})$ for obstructed paths and 37.2 TMU (0.02232 min) per turn. Inter-cell material handling cost is calculated as given in Eq. (1.5).

Equation (2) determines the number of times that an operation at machine $m_{i, j}$ immediately follows an operation at machine $m_{i^{\prime}, j^{\prime}}$.

Equation (3) guarantees that the total number of machines in plant floor should be greater than or equal to summation of number of machines in cells and setup area for a particular period. It prevents additional machine procurement when generating dynamic cells.

In a dynamic production environment, it is possible to have fluctuations of product demand during different periods. Workload for the production environment must be balanced among the cells to prevent possible complications arise due to unbalanced workload. One of the possible issues due to unbalanced workload is operators assigned to different cells may get different workloads and thereby have different incentive ceilings. It may result in operator frustration due to feel of unfairness. Developed model considers three main approaches of cell workload balancing based on possible demand fluctuations. If the product demand for particular period is significantly lower than other periods of considered planning horizon, two approaches are considered to balance the cell workload. First approach is reducing number of operating cells by disintegrating the existing cells from previous period and forming minimum number of cells in current period. Since the developed model assumes existing machines are used to generate dynamic cells, first approach will lead to machine idling in the particular period. Second approach is to operate with reduced workload that is equally distributed among available machines of the period. This will lead to underutilization of cells. If the workload for particular period is not less than other periods, third approach is used to balance the workload among optimum the number of cells, while ensuring maximum resource utilization.

Workload balancing constraint, Eq. (4) is formulated to address those three approaches. By using Eq. (4), it is possible to customize the workload balancing among cells as per the desired approach. The factor $q \in[0,1]$ where, $\{q=0 \leq q \leq 1\}$ is used to determine the extent of workload balance between the dynamic cells. Setting $q \approx 0$ while simultaneously reducing the number of operating cells $(K)$, corresponds to the first approach used when total workload leads to underutilized resources. Second approach can be satisfied by setting $q \approx 0$ with unchanged number of cells. Third approach considers $q \approx 1$ with equally distributed workload while operating optimal number of cells with maximum machine utilization.

The part processing on machines is limited by available machine capacity for a particular period. In ideal situation, the total machine capacity, i.e., shift operating time can be utilized for part processing. Practically, machine capacities are limited due to possible machine breakdowns and setup activities. Using shift time as the available machine capacity is erroneous in this situation. Constraint given in Eq. (5) limits the part processing capability of all machine types based on total machine capacity available for individual machine types.

In case of labor-intensive manufacturing industries, simultaneous processing of multiple different part types within a single cell will lead to forgetting effect, complicated supervision and increased machine stoppages due to variable machine settings. Hence, the maximum number of part types assigned to a single cell is limited to one at a time by using Eq. (6).

Equations (7) and (8) are used to define integer and binary variables.

\section{Linearization of the proposed model}

The developed model is nonlinear due to the terms (1.2), (1.3), (1.4) and (1.5) of the objective function, the constraints Eq. (2), and Eq. (5).

For the term (1.2), the nonlinear term $\left(1-b_{k^{\prime}, h, m_{i, j}}\right)$. $\left(1-b_{k,(h+1), m_{i, j}}\right) \cdot b_{k, h, m_{i, j}} \cdot b_{k^{\prime},(h+1), m_{i, j}}$ can be linearized by Eqs. (9)-(14) and is replaced by the variable $w_{m_{i, j}, k, k^{\prime}, h,(h+1)}$. $w_{m_{i, j}, k, k^{\prime}, h,(h+1)}=\left(1-b_{k^{\prime}, h, m_{i, j}}\right) \cdot\left(1-b_{k,(h+1), m_{i, j}}\right) \cdot b_{k, h, m_{i, j}} \cdot b_{k^{\prime},(h+1), m_{i, j}}$

$w_{m_{i, j}, k, k^{\prime}, h,(h+1)} \leq\left(1-b_{k^{\prime}, h, m_{i, j}}\right)$

$w_{m_{i, j}, k, k^{\prime}, h,(h+1)} \leq\left(1-b_{k,(h+1), m_{i, j}}\right)$

$w_{m_{i, j}, k, k^{\prime}, h,(h+1)} \leq b_{k, h, m_{i, j}}$

$w_{m_{i, j}, k, k^{\prime}, h,(h+1)} \leq b_{k^{\prime},(h+1), m_{i, j}}$

$w_{m_{i, j}, k, k^{\prime}, h,(h+1)} \geq\left(1-b_{k^{\prime}, h, m_{i, j}}\right)+\left(1-b_{k,(h+1), m_{i, j}}\right)+b_{k, h, m_{i, j}}$ $+b_{k^{\prime},(h+1), m_{i, j}}-4.5$

The nonlinear term of the term (1.3), $\left(1-b_{k, h, m_{i, j}}\right)\left(1-b_{k^{\prime}, h, m_{i, j}}\right) \cdot \delta_{h, m_{i, j}} \cdot b_{k,(h+1), m_{i, j}}$ was linearized by replacing it from the variable $x_{k, h, m_{i, j}}$ as given by Eqs. (15)-(20).

$x_{k, h, m_{i, j}}=\left(1-b_{k, h, m_{i, j}}\right)\left(1-b_{k^{\prime}, h, m_{i, j}}\right) \cdot \delta_{h, m_{i, j}} \cdot b_{k,(h+1), m_{i, j}}$

$x_{k, h, m_{i, j}} \leq\left(1-b_{k, h, m_{i, j}}\right)$ 


$$
\begin{aligned}
& x_{k, h, m_{i, j}} \leq\left(1-b_{k^{\prime}, h, m_{i, j}}\right) \\
& x_{k, h, m_{i, j}} \leq \delta_{h, m_{i, j}} \\
& x_{k, h, m_{i, j}} \leq b_{k,(h+1), m_{i, j}} \\
& x_{k, h, m_{i, j}} \geq\left(1-b_{k, h, m_{i, j}}\right)+\left(1-b_{k^{\prime}, h, m_{i, j}}\right)+\delta_{h, m_{i, j}} \\
& \quad+b_{k,(h+1), m_{i, j}}-4.5
\end{aligned}
$$

$b_{k,(h+1), m_{i, j}} \cdot \mu_{m_{i, j}, O_{t, n}} \cdot \omega_{m_{i, j}, l^{\prime}, O_{t, n} .} \cdot e_{l^{\prime},(h+1), m_{i, j}} \cdot e_{l, h, m_{i, j}}$ is the nonlinear term in (1.4) of the objective function. It was replaced by $y_{k, h, m_{i, j}}$ as given in Eqs. (21)-(27).

$y_{k, h, m_{i, j}}=b_{k,(h+1), m_{i, j}} \cdot \mu_{m_{i, j}, O_{t, n}} \cdot \omega_{m_{i, j}, l^{\prime}, O_{t, n}} \cdot e_{l^{\prime},(h+1), m_{i, j}} \cdot e_{l, h, m_{i, j}}$

$y_{k, h, m_{i, j}} \leq b_{k,(h+1), m_{i, j}}$

$y_{k, h, m_{i, j}} \leq \mu_{m_{i, j}, O_{t, n}}$

$y_{k, h, m_{i, j}} \leq \omega_{m_{i, j}, l^{\prime}, O_{t, n}}$

$y_{k, h, m_{i, j}} \leq e_{l^{\prime},(h+1), m_{i, j}}$

$y_{k, h, m_{i, j}} \leq e_{l, h, m_{i, j}}$

$y_{k, h, m_{i, j}} \geq b_{k,(h+1), m_{i, j}}+\mu_{m_{i, j}, O_{t, n}}+\omega_{m_{i, j}, l^{\prime}, O_{t, n}}+e_{l^{\prime},(h+1), m_{i, j}}$

$+e_{l, h, m_{i, j}}-5.5$

Nonlinear

term $b_{k, h, m_{i, j}} \cdot \mu_{m_{i, j}, O_{t, n}} \cdot b_{k^{\prime}, h, m_{i^{\prime}, j^{\prime}}} \cdot \mu_{m_{i^{\prime}, j^{\prime}}, O_{t,(n+1)}} \cdot f_{t, m_{i, j}, m_{i^{\prime}, j^{\prime}}}$ of the term (1.5) is linearized by replacing it by $z_{k, h, m_{i, j}}$ as given in Eqs. (28)-(34).

$$
\begin{aligned}
z_{k, h, m_{i, j}} & =b_{k, h, m_{i, j}} \cdot \mu_{m_{i, j}, O_{t, n}} \cdot b_{k^{\prime}, h, m_{i^{\prime} j^{\prime}}} \cdot \mu_{m_{i^{\prime} j^{\prime}}, O_{t,(n+1)}} \cdot f_{t, m_{i, j}, m_{i^{\prime}, j^{\prime}}} \\
z_{k, h, m_{i, j}} \leq & b_{k, h, m_{i, j}} \\
z_{k, h, m_{i, j}} \leq & \mu_{m_{i, j}, O_{t, n}} \\
z_{k, h, m_{i, j}} \leq & b_{k^{\prime}, h, m_{i^{\prime} j^{\prime}}} \\
z_{k, h, m_{i, j}} \leq & \mu_{m_{i^{\prime} j^{\prime}}, O_{t,(n+1)}} \\
z_{k, h, m_{i, j}} \leq & f_{t, m_{i, j}, m_{l^{\prime}, j^{\prime}}} \\
z_{k, h, m_{i, j}} \geq & b_{k, h, m_{i, j}}+\mu_{m_{i, j}, O_{t, n}}+b_{k^{\prime}, h, m_{i^{\prime} j^{\prime}}}+\mu_{m_{t^{\prime} j^{\prime}}, O_{t,(n+1)}} \\
& \quad+f_{t, m_{i, j}, m_{l^{\prime}, j^{\prime}}}-5.5
\end{aligned}
$$

The nonlinear terms $\mu_{m_{i, j}, O_{t, n}} \cdot \mu_{m_{i^{\prime}, j^{\prime}}, O_{t,(n+1)}}$ and $\mu_{m_{i^{\prime} j^{\prime}}, O_{t, n}} \cdot \mu_{m_{i, j}, O_{t,(n+1)}}$ are replaced by $a_{k, h, m_{i, j}}$ and $v_{k, h, m_{i, j}}$, respectively. Linearization is given in Eqs. (35)-(42).

$$
\begin{aligned}
& a_{k, h, m_{i, j}}=\mu_{m_{i, j}, O_{t, n}} \cdot \mu_{m_{i^{\prime} j^{\prime}}, O_{t,(n+1)}} \\
& a_{k, h, m_{i, j}} \leq \mu_{m_{i, j}, O_{t, n}} \\
& a_{k, h, m_{i, j}} \leq \mu_{m_{i^{\prime}, j^{\prime}}, O_{t,(n+1)}}
\end{aligned}
$$

$a_{k, h, m_{i, j}} \geq \mu_{m_{i, j}, O_{t, n}}+\mu_{m_{i^{\prime} j^{\prime}}, O_{t,(n+1)}}-1$

$v_{k, h, m_{i, j}}=\mu_{m_{i^{\prime}, j^{\prime}}, O_{t, n}} \cdot \mu_{m_{i, j}, O_{t,(n+1)}}$

$v_{k, h, m_{i, j}} \leq \mu_{m_{i^{\prime} j^{\prime}}, O_{t, n}}$

$v_{k, h, m_{i, j}} \leq \mu_{m_{i, j}, O_{t,(n+1)}}$

$v_{k, h, m_{i, j}} \geq \mu_{m_{i^{\prime} j^{\prime}}, O_{t, n}}+\mu_{m_{i, j}, O_{t,(n+1)}}-1$

$\mu_{m_{i, j}, O_{t, n}} \cdot b_{k, h, m_{i, j}}$ the nonlinear term in Eq. (5) can be replaced by as given in Eqs. (43)-(46).

$\beta_{k, h, m_{i, j}}=\mu_{m_{i, j}, O_{t, n}} \cdot b_{k, h, m_{i, j}}$

$\beta_{k, h, m_{i, j}} \leq \mu_{m_{i, j}, O_{t, n}}$

$\beta_{k, h, m_{i, j}} \leq b_{k, h, m_{i, j}}$

$\beta_{k, h, m_{i, j}} \geq \mu_{m_{i, j}, O_{t, n}}+b_{k, h, m_{i, j}}-1$

Equation (47) determines the values of defined variables for linearization.

$w_{k, h, m_{i, j}}, x_{k, h, m_{i, j}}, y_{k, h, m_{i, j}}, z_{k, h, m_{i, j}}, a_{k, h, m_{i, j}}, \beta_{k, h, m_{i, j}} \in\{0,1\}$

\section{Solution approach}

The cell formation problem is considered as NP-hard (nondeterministic polynomial hard) combinatorial optimization problem due to solution complexity (Bayram and Sahin 2016; Rodriguez Leon et al. 2013). Due to solution complexity, manual computation to obtain solutions may produce erroneous results.

LINGO, CPLEX and GAMS are the most commonly used software packages to obtain optimal solutions for mathematical programming models (Agrawal et al. 2015; Esmailnezhad et al. 2015; Anbumalar and Raja Chandra Sekar 2015; Pinheiro et al. 2016; Azadeh et al. 2015; Kasimbeyli et al. 2010).

The developed model is solved by generating a program code using Lingo 16.0 software package.

\section{Model evaluation and validation}

\section{Detailed description of the factories selected for the evaluation and validation of the developed model}

Case studies on three different apparel manufacturing factories were selected for the evaluation and validation of the developed model. The program code generated on Lingo 16.0 software package is used to identify the optimal dynamic cells for the collected data from factories. These 
factories are referred as Factory 1, 2 and 3. Data collection was done in production/assembly department.

Semi-automatic sewing machines are used in majority of the apparel manufacturing plants for past few decades (Zhao and Yang 2011). Therefore, operator should be continually attended to control the machine to process a particular operation. According to the analysis done by Zhao and Yang (2011) and Moll et al. (2009), over 90\% of the operations in production department of apparel industry is done by using semi-automatic machines. Similar situation is observed in the selected factories for case studies. Percentage of semi-automatic machines used in production department of factory 1, 2 and 3 are 95.7, 92.0 and 98.1, respectively. All the selected factories are currently using product layouts with machine sharing in their production environments.

\section{Model validation procedure}

The values of cost terms used in objective function (Sect. 3.1.5) are calculated from the collected data on current layouts. Thereafter, these total cost values of current layouts are used to calculate the cost-saving percentage when applying the obtained optimal dynamic cells for same data sets. Cost-saving percentage is calculated by formula given in Eq. (48).

Cost saving percentage $=\left(\frac{T_{\mathrm{L}}-T_{\mathrm{D}}}{T_{\mathrm{L}}}\right) \times 100 \%$

where $T_{\mathrm{L}}$ summation of considered cost terms of current layout system, $T_{\mathrm{D}}$ optimal cost value for objective function of developed model.

Criteria used for evaluating and determining the validity of developed model is as follows.

if $\left(\frac{T_{\mathrm{L}}-T_{\mathrm{D}}}{T_{\mathrm{L}}}\right) \times 100 \%>0$

model is validated. Otherwise, model is invalid in minimizing cost terms.

Developed model was evaluated and validated by incorporating the total cost of machine relocations, machine setups and material handling calculated for the currently used product layouts in selected factories. Summary of the number of part types and number of machine

Table 1 Number of part types and machine types used for model validation

\begin{tabular}{lll}
\hline Factory & Number of part types & Number of machine types \\
\hline 1 & 21 & 13 \\
2 & 11 & 15 \\
3 & 18 & 12 \\
\hline
\end{tabular}

types used for model validation in factory 1,2 and 3 are given in Table 1.

Initially, the developed model was evaluated by using data collected from Factory 1. According to the initial evaluation based on Factory 1, the developed model resulted in $31.12 \%$ of total costs saving for the considered three cost terms. After the initial evaluation the model was validated by using data collected from Factory 2 and 3.

\section{Numerical example}

Outputs of the developed system are presented by using a numerical example by considering data collected from factory 2 for 11 part types with 15 machine types. Input data used for the numerical example are given in "Appendix A".

Part families and respective part types of optimal solutions for the numerical example are given in Table 2. Table 3 shows part types and their respective dynamic cells with number of machines of each machine type during two periods. Assigned machine numbers of each machine type to the respective dynamic cell are given in Table 4. Corresponding cost saving is $34.60 \%$ for the given numerical example.

\section{Results and discussion}

Resultant cost-saving percentages for individual cost terms and total cost of the objective function for factory 1,2 and 3 are given in Table 5 .

Table 2 Resultant part families and corresponding part types

\begin{tabular}{ll}
\hline Part family & Part type $(t)$ \\
\hline 1 & $2,5,4$ \\
2 & $6,10,1,3$ \\
3 & $8,7,9$ \\
\hline
\end{tabular}

Table 3 Part types and their respective dynamic cells with number of machines of each machine type

\begin{tabular}{|c|c|c|c|c|c|c|c|c|c|c|c|c|c|c|c|}
\hline \multirow[t]{2}{*}{$t$} & \multirow[t]{2}{*}{$k$} & \multirow[t]{2}{*}{$h$} & \multicolumn{13}{|c|}{ Number of machines of type $i$} \\
\hline & & & 1 & 2 & 3 & 4 & 5 & 6 & 7 & 8 & 9 & 10 & 11 & 12 & 13 \\
\hline 2 & 1 & 1 & 1 & 3 & 1 & 4 & 1 & 1 & 2 & 0 & 0 & 0 & 0 & 0 & 0 \\
\hline 5 & 2 & 2 & 1 & 3 & 1 & 4 & 2 & 0 & 2 & 0 & 0 & 0 & 0 & 0 & 0 \\
\hline 4 & 3 & 1 & 1 & 3 & 1 & 0 & 3 & 3 & 2 & 0 & 0 & 0 & 0 & 0 & 0 \\
\hline 6 & 4 & 1 & 2 & 1 & 0 & 3 & 2 & 1 & 2 & 3 & 2 & 0 & 0 & 0 & 0 \\
\hline 10 & 5 & 1 & 1 & 2 & 0 & 2 & 1 & 1 & 2 & 2 & 2 & 0 & 0 & 0 & 1 \\
\hline 1 & 6 & 2 & 1 & 1 & 1 & 2 & 3 & 1 & 2 & 2 & 2 & 0 & 0 & 0 & 0 \\
\hline 3 & 7 & 2 & 2 & 3 & 1 & 3 & 0 & 2 & 3 & 1 & 1 & 0 & 0 & 0 & 0 \\
\hline 8 & 8 & 1 & 1 & 0 & 1 & 1 & 2 & 1 & 2 & 0 & 1 & 1 & 2 & 2 & 1 \\
\hline 7 & 9 & 2 & 0 & 1 & 0 & 0 & 3 & 4 & 2 & 1 & 1 & 0 & 1 & 1 & 1 \\
\hline 9 & 10 & 2 & 2 & 1 & 1 & 0 & 1 & 2 & 1 & 0 & 0 & 1 & 1 & 2 & 0 \\
\hline
\end{tabular}


Table 4 Assigned machines of each machine type to the respective dynamic cell

\begin{tabular}{|c|c|c|c|c|c|c|c|c|c|c|c|c|c|}
\hline \multirow[t]{2}{*}{$k$} & \multicolumn{13}{|c|}{ Assigned machines of each machine type $\left(m_{i, j}\right)$} \\
\hline & 1 & 2 & 3 & 4 & 5 & 6 & 7 & 8 & 9 & 10 & 11 & 12 & 13 \\
\hline 1 & 1 & 9 & 11 & $1,5,6,11$ & 1 & 15 & 3,4 & 0 & 0 & 0 & 0 & 0 & 0 \\
\hline 2 & 12 & $26,10,16$ & 12 & $2,17,28,14$ & 16,14 & 0 & 2,5 & 0 & 0 & 0 & 0 & 0 & 0 \\
\hline 3 & 18,13 & $13,8,6$ & 7 & 0 & $10,11,13$ & $2,3,5$ & 1,8 & 0 & 0 & 0 & 0 & 0 & 0 \\
\hline 4 & 2 & 1 & 0 & $12,15,18$ & 2,3 & 6 & 16,6 & $13,10,1$ & 2,6 & 0 & 0 & 0 & 0 \\
\hline 5 & 10 & 21,22 & 0 & 16,20 & 9 & 8 & 12,7 & 18,21 & 16,10 & 0 & 0 & 0 & 4 \\
\hline 6 & 11,20 & 11 & 5 & 25,19 & $7,8,12$ & 7 & 14,18 & 11,8 & 4,9 & 0 & 0 & 0 & 0 \\
\hline 7 & 23 & $14,12,23$ & 18 & $3,7,10$ & 0 & 12,16 & $11,15,16$ & 2 & 1 & 0 & 0 & 0 & 0 \\
\hline 8 & 16 & 0 & 2 & 9 & 26,4 & 9 & 13,22 & 0 & 10 & 2 & 12,5 & 2,5 & 1 \\
\hline 9 & 0 & 2 & 0 & 0 & 5,6 & $10,15,17,18$ & 20,10 & 14 & 8 & 0 & 1 & 3 & 2 \\
\hline 10 & 21,17 & 4 & 13 & 0 & 18 & 2 & 17 & 0 & 0 & 18 & 14 & 22,1 & 0 \\
\hline
\end{tabular}

Table 5 Cost-saving percentages of selected factories

\begin{tabular}{llll}
\hline Factory & 1 & 2 & 3 \\
\hline Total machine relocation (\%) & 30.29 & 39.87 & 56.05 \\
Machine setup (\%) & 34.10 & 23.49 & 29.61 \\
Inter-cell material handling (\%) & 28.41 & 47.66 & 37.48 \\
Total cost of the objective function (\%) & 31.12 & 34.60 & 47.14 \\
\hline
\end{tabular}

Minimized costs of manufacturing including changeovers and shorter manufacturing lead-times are essential to remain competitive in fast fashion apparel industry. Several researchers have addressed the issues related with supply chain management and retailing decisions of fast fashion apparel products in order to achieve the demanded shorter lead-times (Sabet et al. 2017; Orcao and Pérez 2014; Shen 2014; Zhelyazkov 2011; Zhenxiang and Lijie 2011; Mihm 2010). As the fast fashion apparel segment is introduced recently, there exists a significant gap in the available literature on production layout systems applicable for fast fashion orders (Kentli et al. 2013).

Lago et al. (2013) and Johnson (2003) stated that manufacturing lead-time can be drastically reduced by decreasing changeover time between different products. Positive values of cost-saving percentage (Table 5) imply that the dynamic cells generated from developed model are capable of improving the current layout system with respect to the considered cost terms. It is possible to conclude the validity of developed model in minimizing the considered cost terms for fast fashion apparel products manufactured in dynamic production environment of labor-intensive apparel industry. Hence, the developed model can be used to address the prevailing gap of literature on a layout system appropriate for fast fashion products.

As stated by Malakooti (2014), product layout or assembly line layout is suitable for products with high volume and low product variety. Kumar and Suresh (2006) and, Nunkaew and Phruksaphanrat (2013) mentioned that two of the key problems of product layout are high cost of layout reconfiguration and lack of flexibility. According to the results given in Table 5, the optimal dynamic cells generated from developed model can surpass the product layouts in minimizing the considered cost terms. Therefore, it is encouraged to use the developed model to mitigate the drawbacks of product layout in dynamic production environment.

\section{Future research directions}

According to Bayram and Sahin (2016), Kia et al. (2013) and Mahdavi et al. (2013), cell formation, group layout, group scheduling and resource allocation are four basic stages of designing CMS. This paper is focused on first stage of CMS design and the developed model can be extended to remaining three stages.

The developed model is tested for three selected factories in apparel industry. It is expected to validate the developed model for other labor-intensive manufacturing industries in future.

In the developed model, it is assumed that all the operators and mechanics in production environment are multi-skilled and processing time of each operation is a predefined standard value. As stated by Badiru (2013) and, Mir and Rezaeian (2016), the distribution of skill levels, degree of workforce cross-training, impact of individual operators' learning and forgetting characteristics, motivational issues and attitudes, absenteeism rates, operator turnover rates, frequency of product revisions, and workforce assignment patterns are some of the important factors that determine the performance of the system. The present research can be extended by considering such operator-related issues. 
Forghani et al. (2013) and Suresh and Kay (2012) emphasized that the maximum benefits of cell layout are only achievable by incorporating production control, process planning, wage payment, accounting, purchasing, material handling systems and determining staff level. As stated by Duncan (2011), significant reduction of changeover time can be achieved by scheduling of similar products to cells that are processing same product families. As a future research direction, it is possible to consider these factors when designing dynamic cells for volatile product demand and product mix.
Open Access This article is distributed under the terms of the Creative Commons Attribution 4.0 International License (http://creative commons.org/licenses/by/4.0/), which permits unrestricted use, distribution, and reproduction in any medium, provided you give appropriate credit to the original author(s) and the source, provide a link to the Creative Commons license, and indicate if changes were made.

\section{Appendix A}

See Tables 6, 7, 8, 9, 10 and 11 .
Table 6 Required machine types for operations of part types

\begin{tabular}{|c|c|c|c|c|c|c|c|c|c|c|c|c|c|c|c|c|}
\hline \multirow[t]{2}{*}{$t$} & \multicolumn{16}{|c|}{$O_{t, n}(i)$} \\
\hline & 1 & 2 & 3 & 4 & 5 & 6 & 7 & 8 & 9 & 10 & 11 & 12 & 13 & 14 & 15 & 16 \\
\hline 1 & 1 & 4 & 5 & 2 & 3 & 5 & 6 & 4 & 7 & 8 & 5 & 8 & 9 & 9 & 7 & \\
\hline 2 & 3 & 4 & 1 & 5 & 2 & 2 & 7 & 4 & 4 & 6 & 2 & 7 & 4 & & & \\
\hline 3 & 2 & 3 & 6 & 4 & 1 & 7 & 7 & 4 & 1 & 2 & 7 & 4 & 8 & 9 & 6 & 2 \\
\hline 4 & 7 & 1 & 2 & 5 & 7 & 6 & 3 & 5 & 2 & 5 & 2 & 6 & 6 & & & \\
\hline 5 & 1 & 7 & 3 & 4 & 2 & 2 & 4 & 2 & 4 & 7 & 5 & 5 & 4 & & & \\
\hline 6 & 2 & 4 & 1 & 5 & 9 & 6 & 1 & 4 & 8 & 7 & 5 & 7 & 8 & 8 & 9 & 4 \\
\hline 7 & 2 & 5 & 8 & 13 & 5 & 7 & 9 & 12 & 6 & 7 & 5 & 6 & 6 & 11 & 6 & \\
\hline 8 & 4 & 7 & 11 & 5 & 12 & 3 & 9 & 7 & 12 & 11 & 5 & 10 & 1 & 6 & 13 & \\
\hline 9 & 6 & 11 & 1 & 3 & 5 & 12 & 7 & 1 & 5 & 12 & 10 & 6 & & & & \\
\hline 10 & 4 & 8 & 2 & 9 & 7 & 6 & 7 & 1 & 13 & 4 & 8 & 5 & 9 & 2 & & \\
\hline
\end{tabular}

Table 7 Total number of machines of each machine type

\begin{tabular}{llllllllllllll}
\hline$i$ & 1 & 2 & 3 & 4 & 5 & 6 & 7 & 8 & 9 & 10 & 11 & 12 \\
\hline$J$ & 15 & 21 & 12 & 20 & 23 & 20 & 20 & 11 & 14 & 2 & 5 & 8 & 7 \\
\hline
\end{tabular}

Table 8 Time for machine setting on each machine type

\begin{tabular}{|c|c|c|c|c|c|c|c|c|c|c|c|c|c|}
\hline \multirow[t]{3}{*}{$l$} & \multicolumn{13}{|c|}{$\varphi_{l, m_{i, j}}$} \\
\hline & \multicolumn{13}{|l|}{$i$} \\
\hline & 1 & 2 & 3 & 4 & 5 & 6 & 7 & 8 & 9 & 10 & 11 & 12 & 13 \\
\hline 1 & 13 & 12 & 4 & 3 & 9 & 4 & 20 & 2 & 17 & 15 & 12 & 17 & 14 \\
\hline 2 & 11 & 2 & 3 & 9 & 16 & 5 & 8 & 3 & 12 & 6 & 14 & 8 & 8 \\
\hline 3 & 17 & 14 & 18 & 8 & 6 & 11 & 3 & 8 & 15 & 5 & 5 & 18 & 11 \\
\hline 4 & 2 & 15 & 13 & 10 & 13 & 12 & 17 & 7 & 15 & 8 & 20 & 6 & 9 \\
\hline 5 & 10 & 16 & 7 & 11 & 16 & 7 & 15 & 20 & 12 & 14 & 11 & 17 & 7 \\
\hline 6 & 7 & 3 & 5 & 15 & 3 & 16 & 17 & 3 & 19 & 3 & 4 & 18 & 8 \\
\hline 7 & 20 & 15 & 4 & 5 & 9 & 8 & 18 & 7 & 12 & 17 & 7 & 19 & 10 \\
\hline 8 & 18 & 13 & 12 & 9 & 8 & 13 & 5 & 4 & 12 & 11 & 16 & 5 & 19 \\
\hline 9 & 3 & 14 & 17 & 11 & 18 & 14 & 8 & 17 & 19 & 16 & 20 & 9 & 5 \\
\hline 10 & 11 & 15 & 11 & 11 & 17 & 4 & 13 & 20 & 4 & 2 & 5 & 4 & 9 \\
\hline 11 & 8 & 8 & 18 & 6 & 4 & 16 & 18 & 16 & 16 & 14 & 19 & 4 & 7 \\
\hline 12 & 2 & 20 & 17 & 2 & 7 & 3 & 15 & 13 & 18 & 9 & 20 & 20 & 3 \\
\hline
\end{tabular}


Table 9 Demand data for considered two periods in example

\begin{tabular}{|c|c|c|c|c|c|c|c|c|c|c|}
\hline \multirow[t]{2}{*}{$h$} & \multicolumn{10}{|l|}{$D_{t, h}$} \\
\hline & 1 & 2 & 3 & 4 & 5 & 6 & 7 & 8 & 9 & 10 \\
\hline 1 & 1906 & 1780 & 1257 & 2125 & 2191 & 1677 & 482 & 1730 & 2147 & 2245 \\
\hline 1 & 1982 & 669 & 2421 & 553 & 578 & 481 & 2239 & 2110 & 1207 & 869 \\
\hline
\end{tabular}

Table 10 Standard processing time of each operation of part types

\begin{tabular}{|c|c|c|c|c|c|c|c|c|c|c|c|c|c|c|c|c|}
\hline \multirow[t]{2}{*}{$t$} & \multicolumn{16}{|c|}{$O_{t, n}\left(\eta_{O_{t, n} m_{i, j}}\right)$} \\
\hline & 1 & 2 & 3 & 4 & 5 & 6 & 7 & 8 & 9 & 10 & 11 & 12 & 13 & 14 & 15 & 16 \\
\hline 1 & 0.62 & 0.67 & 3.01 & 1.30 & 0.89 & 0.63 & 1.02 & 1.23 & 0.48 & 2.21 & 1.45 & 1.53 & 2.34 & 1.20 & 1.26 & \\
\hline 2 & 1.12 & 2.31 & 0.23 & 3.01 & 0.55 & 0.28 & 1.41 & 2.01 & 1.15 & 1.11 & 1.03 & 2.11 & 0.36 & & & \\
\hline 3 & 2.0 & 1.08 & 2.10 & 1.22 & 2.03 & 0.41 & 0.89 & 2.03 & 0.39 & 1.05 & 2.31 & 2.61 & 1.55 & 2.46 & 1.25 & 3.06 \\
\hline 4 & 2.11 & 2.53 & 1.53 & 1.33 & 1.25 & 2.15 & 2.45 & 1.64 & 1.36 & 1.36 & 1.68 & 3.02 & 1.55 & & & \\
\hline 5 & 3.33 & 1.35 & 2.01 & 0.23 & 0.89 & 0.92 & 0.59 & 2.82 & 1.22 & 0.66 & 1.32 & 1.40 & 1.28 & & & \\
\hline 6 & 0.69 & 2.13 & 0.88 & 2.03 & 2.30 & 1.35 & 2.01 & 2.22 & 2.36 & 2.89 & 2.65 & 2.36 & 3.01 & 1.23 & 1.99 & 2.69 \\
\hline 7 & 2.98 & 3.66 & 3.48 & 4.33 & 1.32 & 3.11 & 2.89 & 2.36 & 1.32 & 1.65 & 3.21 & 2.35 & 3.33 & 3.21 & 3.01 & \\
\hline 8 & 1.02 & 2.31 & 2.31 & 1.35 & 3.02 & 2.37 & 2.33 & 3.12 & 3.02 & 2.03 & 2.03 & 3.14 & 1.02 & 3.08 & 1.56 & \\
\hline 9 & 1.23 & 3.33 & 2.09 & 2.19 & 1.20 & 3.02 & 3.12 & 0.23 & 1.25 & 0.59 & 3.0 & 2.99 & & & & \\
\hline 10 & 1.32 & 1.56 & 3.06 & 2.31 & 2.03 & 1.09 & 2.85 & 1.10 & 1.11 & 2.22 & 1.21 & 0.97 & 1.55 & 1.35 & & \\
\hline
\end{tabular}

Table 11 Breakdown rates of each machine for considered periods

\begin{tabular}{|c|c|c|c|c|c|c|c|c|c|c|c|c|c|}
\hline \multirow[t]{3}{*}{$j$} & \multicolumn{13}{|l|}{$d F_{t, m_{i, j} t}(h)$} \\
\hline & \multicolumn{13}{|l|}{$i$} \\
\hline & 1 & 2 & 3 & 4 & 5 & 6 & 7 & 8 & 9 & 10 & 11 & 12 & 13 \\
\hline 1 & $1.60 \mathrm{E}-03$ & $8.93 \mathrm{E}-05$ & $4.58 \mathrm{E}-03$ & $7.57 \mathrm{E}-04$ & $1.02 \mathrm{E}-03$ & $0.00 \mathrm{E}+00$ & $1.23 \mathrm{E}-04$ & $0.00 \mathrm{E}+00$ & $2.59 \mathrm{E}-03$ & 7.94E-05 & $9.24 \mathrm{E}-05$ & $3.78 \mathrm{E}-04$ & $5.36 \mathrm{E}-04$ \\
\hline 2 & $4.84 \mathrm{E}-03$ & $1.94 \mathrm{E}-03$ & $0.00 \mathrm{E}+00$ & $4.75 \mathrm{E}-04$ & $9.88 \mathrm{E}-04$ & $7.74 \mathrm{E}-04$ & $6.95 \mathrm{E}-05$ & $2.34 \mathrm{E}-04$ & $6.27 \mathrm{E}-04$ & $7.82 \mathrm{E}-04$ & $2.19 \mathrm{E}-03$ & $9.48 \mathrm{E}-04$ & $2.19 \mathrm{E}-03$ \\
\hline 3 & $1.42 \mathrm{E}-03$ & $5.55 \mathrm{E}-04$ & $6.45 \mathrm{E}-04$ & $5.24 \mathrm{E}-04$ & $3.91 \mathrm{E}-03$ & $0.00 \mathrm{E}+00$ & $2.38 \mathrm{E}-04$ & $6.52 \mathrm{E}-04$ & $7.21 \mathrm{E}-04$ & & $4.11 \mathrm{E}-04$ & $5.49 \mathrm{E}-04$ & $1.54 \mathrm{E}-03$ \\
\hline 4 & $8.71 \mathrm{E}-05$ & $5.66 \mathrm{E}-04$ & $1.00 \mathrm{E}-03$ & $8.60 \mathrm{E}-04$ & $0.00 \mathrm{E}+00$ & $1.54 \mathrm{E}-03$ & $8.19 \mathrm{E}-04$ & $0.00 \mathrm{E}+00$ & $2.86 \mathrm{E}-03$ & & $8.77 \mathrm{E}-04$ & $7.37 \mathrm{E}-04$ & $4.33 \mathrm{E}-04$ \\
\hline 5 & $3.55 \mathrm{E}-04$ & $2.82 \mathrm{E}-04$ & $4.67 \mathrm{E}-04$ & $7.39 \mathrm{E}-04$ & $9.12 \mathrm{E}-05$ & $4.49 \mathrm{E}-04$ & $8.78 \mathrm{E}-04$ & $1.07 \mathrm{E}-03$ & $1.58 \mathrm{E}-04$ & & $4.49 \mathrm{E}-04$ & $1.77 \mathrm{E}-03$ & $3.77 \mathrm{E}-04$ \\
\hline 6 & $7.74 \mathrm{E}-04$ & $3.61 \mathrm{E}-04$ & $6.84 \mathrm{E}-04$ & $1.07 \mathrm{E}-03$ & $8.60 \mathrm{E}-04$ & $5.08 \mathrm{E}-04$ & $4.22 \mathrm{E}-04$ & $0.00 \mathrm{E}+00$ & $2.89 \mathrm{E}-04$ & & & $3.31 \mathrm{E}-04$ & $6.41 \mathrm{E}-04$ \\
\hline 7 & $3.18 \mathrm{E}-03$ & $1.81 \mathrm{E}-04$ & $8.37 \mathrm{E}-04$ & $9.89 \mathrm{E}-04$ & $3.92 \mathrm{E}-04$ & $6.57 \mathrm{E}-04$ & $2.62 \mathrm{E}-03$ & $8.32 \mathrm{E}-03$ & $2.70 \mathrm{E}-04$ & & & $7.60 \mathrm{E}-04$ & \\
\hline 8 & $3.23 \mathrm{E}-03$ & $8.22 \mathrm{E}-04$ & $1.51 \mathrm{E}-03$ & $5.86 \mathrm{E}-04$ & $4.60 \mathrm{E}-04$ & $3.02 \mathrm{E}-04$ & $3.83 \mathrm{E}-04$ & $0.00 \mathrm{E}+00$ & $9.92 \mathrm{E}-04$ & & & $4.92 \mathrm{E}-03$ & \\
\hline 9 & $5.63 \mathrm{E}-04$ & $1.15 \mathrm{E}-04$ & $0.00 \mathrm{E}+00$ & $1.36 \mathrm{E}-03$ & $2.02 \mathrm{E}-04$ & $0.00 \mathrm{E}+00$ & $3.24 \mathrm{E}-04$ & $2.23 \mathrm{E}-03$ & $7.73 \mathrm{E}-04$ & & & & \\
\hline 10 & $1.45 \mathrm{E}-03$ & $4.28 \mathrm{E}-04$ & $6.16 \mathrm{E}-04$ & $6.08 \mathrm{E}-04$ & $9.67 \mathrm{E}-04$ & $4.57 \mathrm{E}-04$ & $1.46 \mathrm{E}-03$ & $4.18 \mathrm{E}-03$ & $4.26 \mathrm{E}-04$ & & & & \\
\hline 11 & $8.01 \mathrm{E}-05$ & $1.49 \mathrm{E}-03$ & $6.92 \mathrm{E}-04$ & $1.21 \mathrm{E}-03$ & $1.60 \mathrm{E}-03$ & $3.95 \mathrm{E}-03$ & $9.76 \mathrm{E}-04$ & $0.00 \mathrm{E}+00$ & $8.98 \mathrm{E}-04$ & & & & \\
\hline 12 & $7.04 \mathrm{E}-04$ & $4.44 \mathrm{E}-03$ & $6.15 \mathrm{E}-03$ & $1.95 \mathrm{E}-03$ & $2.26 \mathrm{E}-03$ & $7.12 \mathrm{E}-04$ & $6.08 \mathrm{E}-04$ & & $0.00 \mathrm{E}+00$ & & & & \\
\hline 13 & $1.42 \mathrm{E}-03$ & $3.16 \mathrm{E}-03$ & & $6.53 \mathrm{E}-04$ & $1.33 \mathrm{E}-03$ & $1.90 \mathrm{E}-03$ & $5.89 \mathrm{E}-04$ & & $7.65 \mathrm{E}-04$ & & & & \\
\hline 14 & $1.06 \mathrm{E}-03$ & $8.76 \mathrm{E}-04$ & & $1.56 \mathrm{E}-04$ & $1.25 \mathrm{E}-03$ & $4.80 \mathrm{E}-04$ & $1.11 \mathrm{E}-04$ & & $1.15 \mathrm{E}-03$ & & & & \\
\hline 15 & $5.75 \mathrm{E}-04$ & $7.30 \mathrm{E}-03$ & & $5.41 \mathrm{E}-04$ & $2.39 \mathrm{E}-03$ & $3.36 \mathrm{E}-04$ & $2.67 \mathrm{E}-04$ & & & & & & \\
\hline 16 & & $1.19 \mathrm{E}-03$ & & $1.57 \mathrm{E}-03$ & $0.00 \mathrm{E}+00$ & $4.89 \mathrm{E}-04$ & $9.98 \mathrm{E}-04$ & & & & & & \\
\hline 17 & & $8.58 \mathrm{E}-04$ & & $0.00 \mathrm{E}+00$ & $5.26 \mathrm{E}-04$ & $9.12 \mathrm{E}-04$ & $1.31 \mathrm{E}-03$ & & & & & & \\
\hline 18 & & $7.94 \mathrm{E}-05$ & & $5.24 \mathrm{E}-04$ & $0.00 \mathrm{E}+00$ & $0.00 \mathrm{E}+00$ & $6.81 \mathrm{E}-04$ & & & & & & \\
\hline 19 & & $9.21 \mathrm{E}-04$ & & $1.18 \mathrm{E}-03$ & $7.50 \mathrm{E}-05$ & $5.56 \mathrm{E}-03$ & $0.00 \mathrm{E}+00$ & & & & & & \\
\hline 20 & & $8.50 \mathrm{E}-04$ & & $7.15 \mathrm{E}-04$ & $4.17 \mathrm{E}-04$ & $8.80 \mathrm{E}-04$ & $1.77 \mathrm{E}-04$ & & & & & & \\
\hline 21 & & $3.25 \mathrm{E}-04$ & & & $6.57 \mathrm{E}-04$ & & & & & & & & \\
\hline 22 & & & & & $2.24 \mathrm{E}-03$ & & & & & & & & \\
\hline 23 & & & & & $1.85 \mathrm{E}-03$ & & & & & & & & \\
\hline
\end{tabular}




\section{References}

Aft LS (2000) Work measurement and methods improvement, vol 9. Wiley, Hoboken

Agrawal AK, Bhardwaj P, Kumar R, Sharma S (2015) Particle swarm optimization for natural grouping in context of group technology application. In: 2015 international conference on IEEE industrial engineering and operations management (IEOM), pp 1-8

Anbumalar V, Raja Chandra Sekar M (2015) Methods for solving cell formation, static layout and dynamic layout cellular manufacturing system problems: a review. Asian J Sci Technol 6(12):2107-2112

Asgharpour MJ, Javadian N (2004) Solving a stochastic cellular manufacturing model by using genetic algorithms. Int $\mathrm{J}$ Eng Trans A 17:145-156

Aus R (2011) Trash to trend - using upcycling in fashion design. Retrieved from: http://vana.artun.ee/popFile.php?id=2269

Azadeh A, Moghaddam M, Nazari-Doust B, Jalalvand F (2015) Fuzzy and stochastic mathematical programming for optimisation of cell formation problems in random and uncertain states. Int $\mathrm{J}$ Oper Res 22(2):129-147

Badiger S, Laxman R (2013) Total quality management and organisation development. Int J Bus Manag Invent 2(7):34-37

Badiru AB (2013) Handbook of industrial and systems engineering. CRC Press, Boca Raton

Bagheri M, Bashiri M (2014) A new mathematical model towards the integration of cell formation with operator assignment and intercell layout problems in a dynamic environment. Appl Math Model 38(4):1237-1254

Balakrishnan J, Hung Cheng C (2005) Dynamic cellular manufacturing under multiperiod planning horizons. J Manuf Technol Manag 16(5):516-530

Bayram H, Şahin R (2016) A comprehensive mathematical model for dynamic cellular manufacturing system design and Linear Programming embedded hybrid solution techniques. Comput Ind Eng 91:10-29

Bhardwaj V, Fairhurst A (2009) Fast fashion: response to changes in the fashion industry. Int Rev Retail Distrib Consum Res 20(1):165-173

Cachon GP, Swinney R (2011) The value of fast fashion: quick response, enhanced design, and strategic consumer behavior. Manag Sci 57(4):778-795

Caro F, Martínez-de-Albéniz V (2015) Fast fashion: business model overview and research opportunities. In: Agrawal N, Smith S (eds) Retail supply chain management. Springer, Boston, pp 237-264

Case K, Newman ST (eds) (2004) Advances in manufacturing technology VIII: proceedings of the 10th national conference on manufacturing research. CRC Press, Boca Raton

Chang CC, Wu TH, Wu CW (2013) An efficient approach to determine cell formation, cell layout and intracellular machine sequence in cellular manufacturing systems. Comput Ind Eng 66(2):438-450

Chary SN (1988) Production and operations management. Tata McGraw-Hill, New York

Cheng TC, Podolsky S (1996) Just-in-time manufacturing: an introduction. Springer, Berlin

Chowdary BV, Slomp J, Suresh NC (2005) A new concept of virtual cellular manufacturing. West Indian J Eng 28(1):45-60

Chung SH, Wu TH, Chang CC (2011) An efficient tabu search algorithm to the cell formation problem with alternative routings and machine reliability considerations. Comput Ind Eng 60(1):7-15

Curry GL, Feldman RM (2010) Manufacturing systems modeling and analysis. Springer, Berlin, pp 117-128
Dalfard VM (2013) New mathematical model for problem of dynamic cell formation based on number and average length of intra and intercellular movements. Appl Math Model 37(4):1884-1896

De Carlo F, Arleo MA, Borgia O, Tucci M (2013) Layout design for a low capacity manufacturing line: a case study. Int J Eng Bus Manag 5:35

Deep K, Singh PK (2015) Design of robust cellular manufacturing system for dynamic part population considering multiple processing routes using genetic algorithm. J Manuf Syst 35:155-163

Deep K, Singh PK (2016) Dynamic cellular manufacturing system design considering alternative routing and part operation tradeoff using simulated annealing based genetic algorithm. Sādhanā 41(9): 1063-1079

Duncan WP (2011) Methods for reducing changeover times through scheduling. University of Rhode Island, Kingston

Egilmez G, Süer GA, Huang J (2012) Stochastic cellular manufacturing system design subject to maximum acceptable risk level. Comput Ind Eng 63(4):842-854

Elavia S (2014) How the lack of copyright protections for fashion designs affects innovation in the fashion Industry. Senior Theses, Trinity College, Hartford

Esmailnezhad B, Fattahi P, Kheirkhah AS (2015) A stochastic model for the cell formation problem considering machine reliability. J Ind Eng Int 11(3):375-389

Forghani K, Mohammadi M, Ghezavati V (2013) Designing robust layout in cellular manufacturing systems with uncertain demands. Int J Ind Eng Comput 4(2):215-226

Giri PK, Moulick SK (2016) Comparison of cell formation techniques in cellular manufacturing using three cell formation algorithms. Int J Eng Res Appl 6(1):98-101

Guo ZX, Ngai EWT, Yang C, Liang X (2015) An RFID-based intelligent decision support system architecture for production monitoring and scheduling in a distributed manufacturing environment. Int J Prod Econ 159:16-28

Hachicha W, Masmoudi F, Haddar M (2006) Principal component analysis model for machine-part cell formation problem in group technology. In: The international conference on advances in mechanical engineering and mechanics (ICAMEM 2006)

Hamedi M, Esmaeilian GR, Ismail N, Ariffin MKA (2012) Capability-based virtual cellular manufacturing systems formation in dual-resource constrained settings using Tabu Search. Comput Ind Eng 62(4):953-971

Heizer J (2016) Operations management, 11/e. Pearson Education India, Noida

Houshyar AN, Leman Z, Moghadam HP, Ariffin MKAM, Ismail N, Iranmanesh H (2014) Literature review on dynamic cellular manufacturing system. In: IOP conference series: materials science and engineering, vol 58, No. 1, p. 012016. IOP Publishing

Ireland F, Dale BG (2001) A study of total productive maintenance implementation. J Qual Maint Eng 7(3):183-192

Islam I, Rahman MF, LeHew ML (2015) Predicting total assembling time for different apparel products utilizing learning curve and time study approaches: a comparative case study. In: International Textile and Apparel Association (ITAA) Annual Conference Proceedings 110

Johnson DJ (2003) A framework for reducing manufacturing throughput time. J Manuf Syst 22(4):283

Jovanovic VM, Mann M, Katsioloudis PJ, Dickerson DL (2014) Enabling multidisciplinary perspective in student design project: fast fashion and sustainable manufacturing systems. Paper presented at 2014 ASEE annual conference \& exposition, Indianapolis, Indiana. https://peer.asee.org/20370 
Kahraman C (2012) Computational intelligence systems in industrial engineering: with recent theory and applications. Springer, Berlin, pp 505-508

Kannan B (2011) Reliability/availability of manufacturing cells and transfer lines (Doctoral dissertation, Auburn University)

Karger DW, Bayha FH (1987) Engineered work measurement: the principles, techniques, and data of methods-time measurement background and foundations of work measurement and methodstime measurement, plus other related material. Industrial Press Inc., New York

Kasimbeyli R, Dincer C, Ozpeynirci S (2010) Sub-gradient based solution approach for cell formation problem with alternative routes. In: International conference 24th mini EURO conference "continuous optimization and information-based technologies in the financial sector” (MEC EurOPT 2010), June 23-26, 2010, Izmir, Turkey

Kentli A, Dal V, Alkaya AF (2013) Minimizing machine changeover time in product line in an apparel industry. J Text Appar/Tekst Konfeks 23(2):159-167

Khannan MSA, Maruf A, Wangsaputra R, Sutrisno S, Wibawa T, (2016) Cellular manufacturing system with dynamic lot size material handling. In: IOP conference series: materials science and engineering, vol 114, No 1, p 012144. IOP Publishing

Kia R, Shirazi H, Javadian N, Tavakkoli-Moghaddam R (2013) A multi-objective model for designing a group layout of a dynamic cellular manufacturing system. J Ind Eng Int 9(1):8

Kumar SA, Suresh N (2006) Production and operations management. New Age International, New Delhi

Kumar PG, Moulick SK (2016) Comparison of cell formation techniques in cellular manufacturing using three cell formation algorithms. Int J Eng Res Appl 6(1):98-101 (Part - 5)

Lago A, Martinez-de-Albeniz V, Moscoso P, Vall A (2013) The role of quick response in accelerating sales of fashion goods. Retrieved from: http://webprofesores.iese.edu/valbeniz/RoleQR Fashion_web.pdf. Accessed 27 Feb 2014

Leflar J (2001) Practical TPM. Productivity Press, Portland

Mahdavi I, Aalaei A, Paydar MM, Solimanpur M (2010) Designing a mathematical model for dynamic cellular manufacturing systems considering production planning and worker assignment. Comput Math Appl 60(4):1014-1025

Mahdavi I, Teymourian E, Baher NT, Kayvanfar V (2013) An integrated model for solving cell formation and cell layout problem simultaneously considering new situations. J Manuf Syst 32(4):655-663

Malakooti B (2014) Operations and production systems with multiple objectives. Wiley, Hoboken

Marsh RF, Meredith JR, McCutcheon DM (1997) The life cycle of manufacturing cells. Int J Oper Prod Manag 17(12):1167-1182

Memic M, Minhas FN (2011) The fast fashion phenomenon: luxury fashion brands responding to fast fashion. The Swedish School of Textiles April.

Mihm B (2010) Fast fashion in a flat world: global sourcing strategies. The International Business \& Economics Research Journal 9(6):55

Mir MSS, Rezaeian J (2016) A robust hybrid approach based on particle swarm optimization and genetic algorithm to minimize the total machine load on unrelated parallel machines. Appl Soft Comput 41:488-504

Mital A, Desai A, Mital A (2017) Fundamentals of work measurement: what every engineer should know. CRC Press, Boca Raton

Mittlehauser M (1997) Employment trends in textiles and apparel, 1973-2005. Monthly Labor Review, August, 1997, pp 24-35

Mo Z (2015) Internationalization process of fast fashion retailers: evidence of H\&M and Zara. Int J Bus Manag 10(3):217
Modrák V (2011) Operations management research and cellular manufacturing systems: innovative methods and approaches: innovative methods and approaches. IGI Global, Hershey

Moll P, Schütte U, Zöll K, Molfino R, Carca E, Zoppi M, Montorsi R (2009) Automated garment assembly and manufacturing simulation. In: Walter L, Kartsounis GA, Carosio S (eds) Transforming clothing production into a demand-driven, knowledge-based, high-tech industry. Springer, London, pp 9-59

Moradgholi M, Paydar MM, Mahdavi I, Jouzdani J (2016) A genetic algorithm for a bi-objective mathematical model for dynamic virtual cell formation problem. J Ind Eng Int 12(3):343-359

Moretta Tartaglione A, Antonucci E (2013) Value creation process in the fast fashion industry: towards a networking approach. In: The 2013 Naples Forum on Service. Service Dominant Logic, Networks \& Systems Theory and Service Science: Integrating Three Perspectives for a New Service Agenda, p 91

Mungwattana A (2000) Design of cellular manufacturing systems for dynamic and uncertain production requirements with presence of routing flexibility (Doctoral dissertation)

Neumann CSR, Fogliatto FS (2013) Systematic approach to evaluating and improving the flexibility of layout in dynamic environments. Manag Prod 20(2):235-254

Niakan F (2015) Design and configuration of sustainable dynamic cellular manufacturing systems (Doctoral dissertation, Lyon, INSA)

Niakan F, Baboli A, Moyaux T, Botta-Genoulaz V (2016) A biobjective model in sustainable dynamic cell formation problem with skill-based worker assignment. J Manuf Syst 38:46-62

Nouri H (2016) Development of a comprehensive model and BFO algorithm for a dynamic cellular manufacturing system. Appl Math Model 40(2):1514-1531

Nouri HA, Leman Z, Moghadam HP, Sulaiman R (2014) Literature review on machine reliability in cellular manufacturing system. Am J Appl Sci 11(12):1964-1968

Nunkaew W, Phruksaphanrat B (2013) Effective fuzzy multi-objective model based on perfect grouping for manufacturing cell formation with setup cost constrained of machine duplication. Songklanakarin J Sci Technol 35(6):715-726

Orcao AIE, Pérez DR (2014) Global production chains in the fast fashion sector, transports and logistics: the case of the Spanish retailer Inditex. Investigaciones Geográficas, Boletín del Instituto de Geografía 2014(85):113-127

Pillai VM, Hunagund IB, Krishnan KK (2011) Design of robust layout for dynamic plant layout problems. Comput Ind Eng 61(3):813-823

Pinheiro RG, Martins IC, Protti F, Ochi LS, Simonetti LG, Subramanian A (2016) On solving manufacturing cell formation via Bicluster Editing. Eur J Oper Res 254(3):769-779

Rafiei H, Ghodsi R (2013) A bi-objective mathematical model toward dynamic cell formation considering labor utilization. Appl Math Model 37(4):2308-2316

Rajput RK (2007) A textbook of manufacturing technology: manufacturing processes. Firewall Media, New Delhi

Rodriguez Leon J, Quiroga Méndez JE, Ortiz Pimiento NR (2013) Performance comparison between a classic particle swarm optimization and a genetic algorithm in manufacturing cell design. Dyna 80(178):29-36

Sabet E, Sabet E, Yazdani N, Yazdani N, De Leeuw S, De Leeuw S (2017) Supply chain integration strategies in fast evolving industries. Int J Logist Manag 28(1):29-46

Sakhaii M, Tavakkoli-Moghaddam R, Bagheri M, Vatani B (2016) A robust optimization approach for an integrated dynamic cellular manufacturing system and production planning with unreliable machines. Appl Math Model 40(1):169-191 
Saxena L, Jain P (2011) Dynamic cellular manufacturing systems design - a comprehensive model. Int $\mathbf{J}$ Adv Manuf Technol 53:11-34. https://doi.org/10.1007/s00170-010-2842-9

Seifoddini S, Djassemi M (2001) The effect of reliability consideration on the application of quality index. Comput Ind Eng 40:65-77. https://doi.org/10.1016/S0360-8352(00)00072-3

Shafigh F, Defersha FM, Moussa SE (2017) A linear programming embedded simulated annealing in the design of distributed layout with production planning and systems reconfiguration. Int J Adv Manuf Technol 88(1-4):1119-1140

Shen B (2014) Sustainable fashion supply chain: lessons from H\&M. Sustainability 6(9):6236-6249

Süer GA, Dagli C (2005) Intra-cell manpower transfers and cell loading in labor-intensive manufacturing cells. Comput Ind Eng 48(3):643-655

Süer GA, Huang J, Maddisetty S (2010) Design of dedicated, shared and remainder cells in a probabilistic demand environment. Int $\mathrm{J}$ Prod Res 48(19):5613-5646

Suresh NC, Kay JM (eds) (2012) Group technology and cellular manufacturing: a state-of-the-art synthesis of research and practice. Springer, Berlin
Tavakkoli-Moghaddam R et al (2011) Solving a new bi-objective model for a cell formation problem considering labor allocation by multi-objective particle swarm optimization. Int J Eng Trans A Basics 24(3):249

Vecchi A, Buckley C (2016) Handbook of research on global fashion management and merchandising. IGI Global

Yadollahi MS et al (2014) Design a bi-objective mathematical model for cellular manufacturing systems considering variable failure rate of machines. Int J Prod Res 52(24):7401-7415

Zhao, L. and Yang, J. (2011) Clothing workshop production line analysis and improvement research based on IE. In: Advanced material research, vol 291-294, pp 3147-3151. Trans Tech Publications, Switzerland

Zhelyazkov G (2011) Agile supply chain: Zara's case study analysis. Design, manufacture \& engineering management. Strathclyde University Glasgow, Velika Britanija, pp 2-11

Zhenxiang W, Lijie Z (2011) Case study of online retailing fast fashion industry. Int J e-Educ e-Bus e-Manag e-Learn 1(3):195

Zohrevand AM, Rafiei Hamed, Zohrevand AH (2016) Multi-objective dynamic cell formation problem: a stochastic programming approach. Comput Ind Eng 98:323-332 